\title{
The Role of MicroRNAs in Myocardial Infarction: From Molecular Mechanism to Clinical Application
}

\author{
Teng Sun, Yan-Han Dong, Wei Du, Chun-Ying Shi, Kun Wang, Muhammad-Akram Tariq, \\ Jian-Xun Wang * and Pei-Feng Li *
}

Institute for Translational Medicine, Qingdao University, Qingdao 266021, China; tengsun@qdu.edu.cn (T.S.); dongyanhande@163.com (Y.-H.D.); mtdw2015@126.com (W.D.); schy1116@163.com (C.-Y.S.);

wangk696@163.com (K.W.); akram@soe.ucsc.edu (M.-A.T.)

* Correspondence: wangjx@qdu.edu.cn (J.-X.W.); peifli@qdu.edu.cn (P.-F.L.);

Tel.: +86-532-8299-1791 (J.-X.W. \& P.-F.L.)

Academic Editors: Kumiko Ui-Tei, Y-h. Taguchi and Andreas Keller

Received: 26 January 2017; Accepted: 27 March 2017; Published: 31 March 2017

\begin{abstract}
MicroRNAs (miRNAs) are a class of small single-stranded and highly conserved non-coding RNAs, which are closely linked to cardiac disorders such as myocardial infarction (MI), cardiomyocyte hypertrophy, and heart failure. A growing number of studies have demonstrated that miRNAs determine the fate of the heart by regulating cardiac cell death and regeneration after MI. A deep understanding of the pathophysiology of miRNA dependent regulatory pathways in these processes is required. The role of miRNAs as diagnostic, prognostic, and therapeutic targets also needs to be explored in order to utilize them in clinical settings. This review summarizes the role of miRNAs in myocardial infarction and focuses mainly on their influence on cardiomyocyte regeneration and cell death including apoptosis, necrosis, and autophagy. In addition, the targets of pro- and anti-MI miRNAs are comparatively described. In particular, the possibilities of miRNA-based diagnostic and therapeutic strategies for myocardial infarction are discussed in this review.
\end{abstract}

Keywords: microRNAs; myocardial infarction; myocardial cell death; cardiomyocyte regeneration; clinical application

\section{Introduction}

\subsection{Introduction of Myocardial Infarction}

Myocardial infarction (MI) is pathologically defined as myocardial cell death due to prolonged ischemia, which is the most severe manifestation of coronary artery disease (CAD). CAD causes over seven million deaths globally every year [1]. Every year, more than 700,000 people suffer from MI, which leads to 120,000 deaths every year in the United States alone. The economic impact of MI is substantial. The direct cost of hospitalization in the United States of America (USA) is at least US $\$ 450$ billion and the loss of productive years of life is also tremendous [2].

The development of CAD can be chronic, by the erosion of endothelium and buildup of plaque and progressive narrowing of the coronary artery. However, a sudden rupture of plaque and formation of thrombus leads to acute MI, which is much more serious. Once the oxygen supply is occluded, the onset of MI is initiated as little as $20 \mathrm{~min}$ after and the complete myocardial cell necrosis happens in a few hours. Prolonged ischemia leads to the loss of heart contractility due to the poor proliferation capability of the myocardial cell. Therefore, the timely revascularization of the occluded artery is the key for MI therapy. Antithrombotic agents, percutaneous coronary intervention, and bypass surgery are usually applied to treat the patients [2,3]. However, these treatments only reduce the severity of $C A D$, rather than restoration of the contractility of the infarcted heart [3-5]. Therefore, 
novel therapeutic strategies to reduce the myocardial cell death and/or stimulate heart regeneration are highly desirable for the future.

\subsection{Overview of miRNA}

Although most of the genome is transcribed into RNAs, there is only $1-2 \%$ of human genome coding for proteins [6]. RNAs without protein coding potential, called non-coding RNAs, had been considered as "junk" product until recent studies confirmed that they are hugely involved in many biological processes. MicroRNAs (miRNAs) are defined as single-stranded non-coding RNAs with around 22 nucleotides. They were first discovered in Caenorhabditis elegans in 1993 [7,8] and now are the most extensively studied subgroup of non-coding RNA.

Most of miRNAs are generated by a canonical pathway. The miRNA coding genes are transcribed to miRNA precursors (pri-miRNAs) by either RNA polymerase II (pol II) or polymerase III (pol III). The pri-miRNAs contain a hairpin structure including the mature RNA sequence, a $5^{\prime}$ cap and a $3^{\prime}$ poly (A) tail. The $5^{\prime}$ cap and $3^{\prime}$ poly (A) are removed by a nuclear complex called microprocessor comprising Di-George syndrome critical region (DGCR) 8 and RNase III endonuclease Drosha. The resulting hairpin RNAs (pre-miRNAs) are then transported from the nucleus to the cytoplasm by Exportin-5 and RAN-GTP. In the cytoplasm the terminal loop of the hairpin structure is cleaved by a complex comprising of RNase III endonuclease Dicer, TAR RNA binding protein (TARBP) and protein kinase $R$ (PKR) activator (PACT). The remaining RNA duplex interacts with Argonaute proteins (AGO) to form miRNA-induced silencing complex (miRISC), by which the passenger strand of miRNA is degraded and the mature miRNA retained [9].

In addition, some miRNAs are generated via non-canonical pathways, which may provide bona fide alternation to the canonical pathway. For example, small RNAs derived from endogenous short hairpin RNAs, tRNAs or tRNA like precursors, may bypass the Drosha-mediated process $[10,11]$, during which Dicer processing is still required to remove the hairpin loop of these RNAs except for biogenesis of miR-451. In the case of miR-451, AGO catalytic activity directly cleaves pre-miR-451 in the middle of the $3^{\prime}$ strands of pre-miR-451 and further it is trimmed by PARN to generate a mature miR-451 [12,13].

\subsection{Regulation of $m R N A$ Translation and Decay by miRNA}

MicroRNAs regulate protein synthesis usually by base-pairing with $3^{\prime}$ untranslated region ( $3^{\prime}$ UTR) of mRNAs, with some exceptions in which they interact with $5^{\prime}$ untranslated region (5' UTR) of mRNA [14,15]. It is predicted that around $60 \%$ of total mammalian mRNAs could be regulated by miRNAs. The miRNAs achieve their function by binding with AGO proteins and other miRISC components like GW182 [14,15]. GW182 contains a GW repeats domain, glutamine (Q)-rich region, domain of unknown function (DUF), and a RNA recognition motif domain (RRM) and it usually works as a downstream of AGO. The C-terminal region including DUF and RRM is essential for translation repression $[16,17]$. miRNAs mediate translational repression either at the initiation step or the post-initiation steps [18]. At the initial stage of cap-dependent translation, the 40S ribosomal subunit binds to mRNA near $5^{\prime}$ cap and it scans the mRNA until it recognizes the start codon where the 605 ribosomal subunit joins the complex. miRNAs interact with the eIF4F complex and inhibit the recruitment of $40 \mathrm{~S}$ ribosomal subunits to the $5^{\prime}$ cap. Additionally, miRNAs repress the initiation of translation by inhibiting the joining of the 60S ribosomal subunit [18] (Figure 1). A large body of evidence also supports the fact that miRNAs inhibit elongation and termination steps. During these steps miRNAs may either cause premature termination and subsequent ribosome drop-off, or recruit proteolytic enzymes that can degrade the nascent polypeptides, which leads to blockage of post-initiation processing [18-21]. 


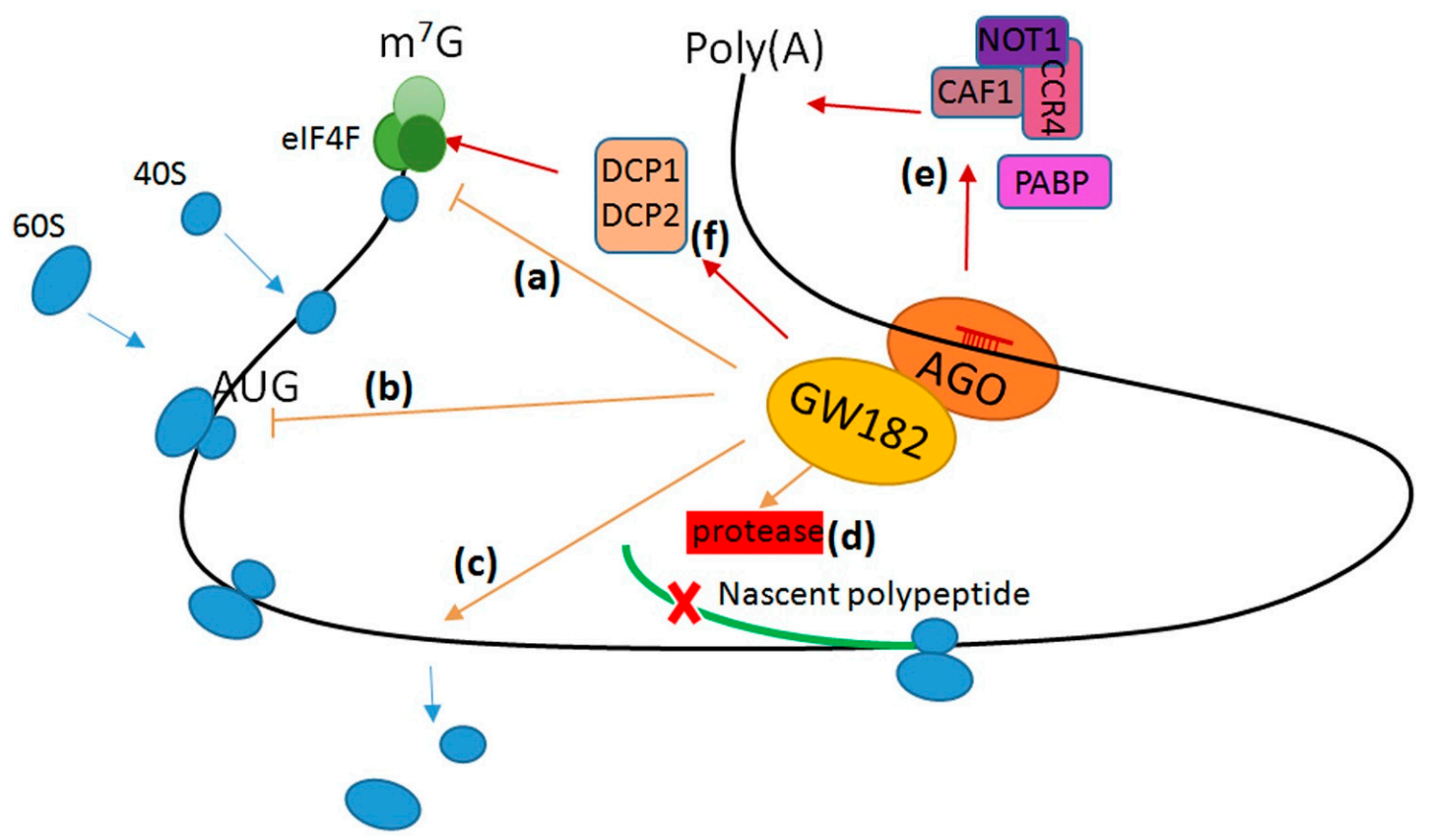

Figure 1. Schematic diagram of miRNA-mediated mRNA translational repression and decay. (a) miRNA-induced silencing coplex (miRISC) prevents the eIF4E-cap recognition and 40S ribosomal subunits recruitment; (b) $60 \mathrm{~S}$ ribosomal subunit joining is prevented by miRISC; (c) Translation is inhibited by ribosome drop-off; (d) Translation is blocked by nascent polypeptide degradation; (e) miRISC interacts with Poly (A)-binding protein (PABP), CCR4-assocated factor (CAF1), negative on TATA-less (NOT1), and carbon catabolite repression 4 (CCR4), which mediate deadenylation, decapping, and mRNA decay; (f) miRISC interacts with decapping factor DCP1/2 for decapping and mRNA decay. Blue arrows represent the recruitment and disassociation of 40S/60S ribosomal subunits. Orange arrows represent the process fancilited by AGO/GW182. Orange T blocks represent the process prevented by AGO/GW182. Red cross (x), degradation of nascent polypeptide. Red arrows represent the interaction between AGO/GW182 and indicated factors and their function upon miRNA regulation.

In cytoplasm, mRNA is protected from degradation by the $5^{\prime}$ cap structure and a $3^{\prime}$ poly (A) tail. miRISC component GW182 recruits the carbon catabolite repression 4 (CCR4)- negative on TATA-less (NOT1) deadenylase complex to mRNA and facilitates AGO association with CCR4-assocated factor (CAF1). These factors are involved in the removal of poly (A) tail which subsequently results in mRNA decay [22-24]. GW182 also interacts with Poly (A)-binding protein (PABP), which mediates both translation initiation and mRNA deadenylation [24]. In addition, GW182 mediates 5' decapping via interaction with decapping factor DCP1 and DCP2 [25]. All together miRNAs mediate mRNA decay via both the deadenylation and decapping mechanism [18].

\section{Specific Function of MicroRNAs in Cardiac Cell Death}

Cardiac cell death plays a critical role in the pathogenesis of myocardial infarction, due to the terminal differentiation and loss of regenerative ability of cardiomyocytes. Myocardial infarction usually involves three main types of cell death process including apoptosis, necrosis, and autophagy [26-28]. Cardiac cell death processes are regulated by a variety of molecules, among which miRNAs have shown outstanding regulatory functions. Recently, a large body of research has emphasized the importance of miRNAs in regulating apoptosis, necroptosis, and autophagy in cardiomyocytes, which play a decisive role in myocardial infarction (Figure 2). The latest findings on the specific function of miRNAs in cardiac cell death are discussed in the following sections. 


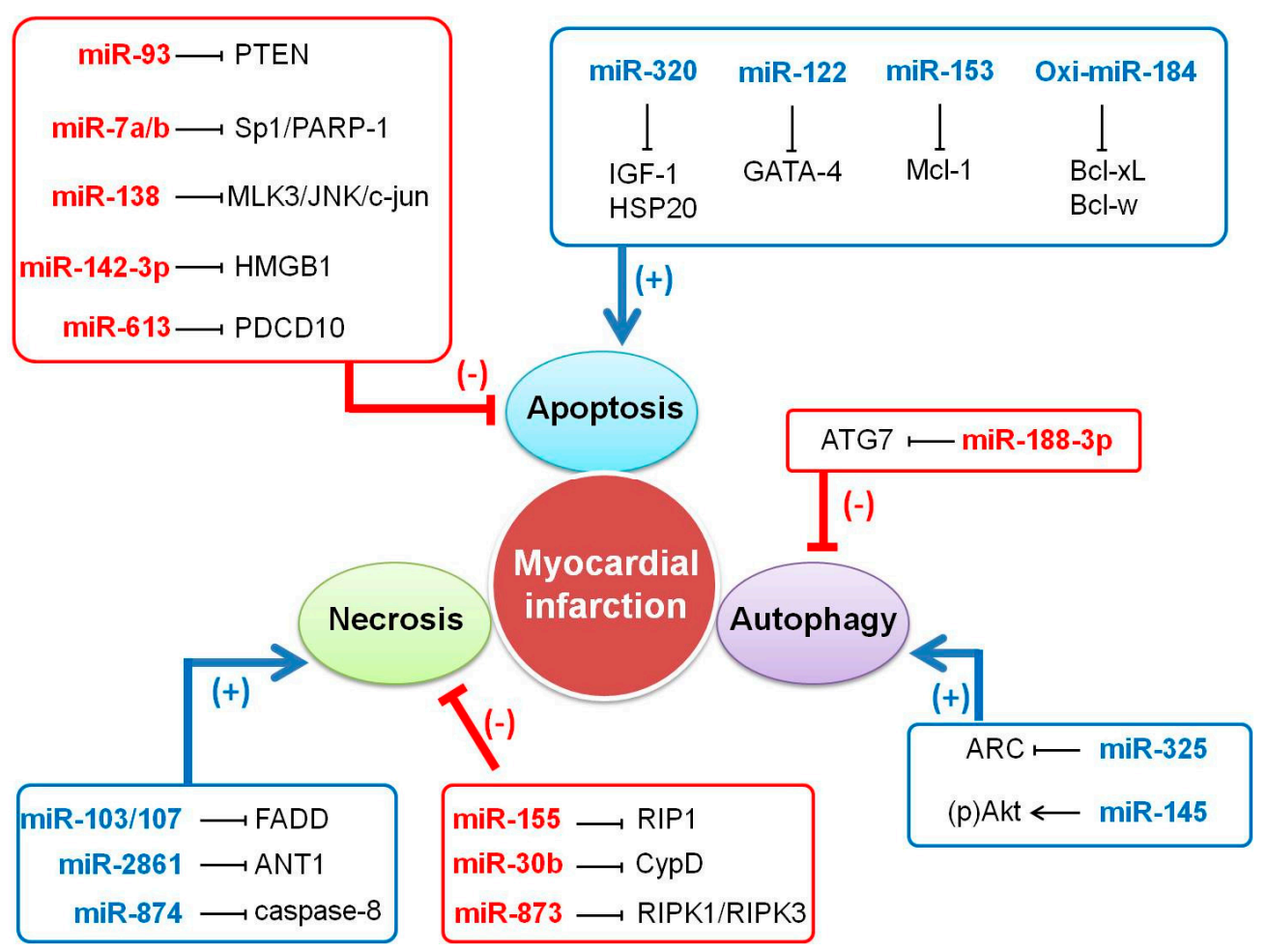

Figure 2. Overview of the role of miRNAs-regulated myocardial cell death in MI. See text for detailed explanations. Blue arrows and plus sign indicate that the final effect is the activation of cell death. $\mathrm{T}$ bars and minus sign indicates that the final effect is the inhibition of cell death.

\subsection{Apoptosis}

Apoptosis is a type of programmed cell death executed through the extrinsic pathway through death receptors [29] and/or the intrinsic pathway mainly by mitochondria [30,31]. The signal transduction of apoptosis is mediated by many pro-apoptosis and/or anti-apoptosis factors including caspase family [31], Bcl-2 family, [32] cytochrome c [33], and p53 [34].

miRNAs regulate apoptosis usually through targeting pro-apoptotic factors-related pathways. A great variety of apoptosis-related miRNAs or miRNA families have been identified. Much attention has been paid to the let-7 family of miRNAs [35], miR-34 family, [36,37] miR-21 family [38,39], miR-30 family [40], miR-125b [41], and miR-138 [42] in the field of cardiac diseases due to their impact on cardiomyocyte apoptosis. Besides, the research on the link between miRNA and apoptosis regulatory network is expanding and more pro- and anti-apoptotic miRNAs have been recently identified. In an experimental model, overexpression of miR-93 inhibits cardiomyocyte apoptosis by targeting phosphatase and tensin homolog (PTEN) in mice with ischemia/reperfusion (I/R) injury [43]. In adult cardiomyocytes (H9C2), hypoxia inducible apoptosis can be inhibited by miR-7a/b-Sp1/PARP-1 pathways [44] while miR-138 exhibits a protective effect against hypoxia-induced apoptosis via MLK3/JNK/c-jun pathway in H9C2 cell lines [42]. Similarly, miR-142-3p targets the high mobility group box 1 (HMGB1) [45] and miR-613 targets PDCD10 [46] and inhibits apoptotic cell death in cardiomyocytes. In contrast, miR-320 promotes apoptosis by targeting insulin-like growth factor-1 (IGF-1) which inhibits cardiomyocyte apoptosis by down-regulating p-ASK, p-JNK, p-p38, Bax and Caspase-3 levels, and upregulating Bcl-2 levels. Inhibition of miR-320 up-regulates the level of IGF1 mRNA [47]. Likewise, the knockdown of miR-122, an apoptosis-related microRNA, attenuates hypoxia/reoxygenation-induced myocardial cell apoptosis by upregulating GATA-4 [48]. In oxidative stress condition, the expression of miR-153 is significantly increased, and inhibition of endogenous miR-153 can block cardiomyocyte apoptosis [49]. 
In particular, an inspirational study demonstrated that oxidative modification of miRNAs is implicated in cardiomyocyte apoptosis. Wang et al. identified that several miRNAs are oxidatively modified by various oxidant systems, among which miR-184, miR-204-3p, and miR-139-3p are highly oxidized under oxidative stress condition. They observed that this oxidation enables miRNAs to negatively regulate gene expression through mismatching, whereas the native miRNAs could not. For instance, the oxi-miR-184 mismatches with the $3^{\prime}$ UTRs of anti-apoptotic genes Bcl-xL and Bcl-w and leads to reduction in their levels, which subsequently leads to apoptotic cell death of cardiomyocytes. The oxidized miR-204-3p inhibits pancreatic and duodenal homeobox 1C-terminal inhibiting factor (Pcif1) and oxi-miR-139-3p substantially induces a reduction in the luciferase activity and protein levels of RNA (guanine-7-) methyltransferase (RNMT), but not by native miR-204-3p or miR-139-3p. These findings enrich miRNAs-based pathways in regulating apoptosis [50].

Thus, miRNAs function as angels or devils in apoptosis regulatory network. It is expected that more miRNAs and their targets in cardiomyocyte apoptosis program could be unveiled in the future.

\subsection{Necroptosis}

For a long time, Necrosis was considered as a passive and accidental form of cell death. In recent years, a growing number of studies demonstrated that necrosis is regulated by multiple regulators and hence termed as "programmed necrosis" or "necroptosis". Necroptosis is usually initiated by tumor necrosis factor (TNF)- $\alpha$ and TNF- $\alpha$ receptor (TNFR1), and then mediated by receptor-interacting serine/threonine-protein kinase (RIPK) 1 and 3 pathways [51].

Recent research demonstrated that miRNAs participate in necrotic process in cardiac disorders. In $\mathrm{H} 9 \mathrm{C} 2$ cells, miR-103/107 levels are elevated in $\mathrm{H}_{2} \mathrm{O}_{2}$-induced necrosis and knockdown of endogenous miR-103/107 antagonizes necrotic cell death. The molecular study revealed that miR-103/107 provokes cardiomyocyte necrosis through targeting Fas-associated protein with death domain (FADD) [27]. Cyclophilin D promotes necrosis in myocardial infarction, which is suppressed by miR-30b through inhibition of its translation. Cardiac-specific enhancement of miR-30b expression in transgenic mice exhibits reduced necrosis and myocardial infarct size following ischemia/reperfusion injury [52]. Similarly, overexpression of miR-155 attenuates necrotic cell death via targeting RIP1 in cardiomyocyte progenitor cells [53]. miR-2861 and adenine nucleotide translocase 1 (ANT1) constitute an axis to promote necrosis in the heart. Forced expression of miR-2861 triggers $\mathrm{H}_{2} \mathrm{O}_{2}$-induced necrotic cell death through targeting ANT1, while knockdown of miR-2861 attenuates necrosis [54]. Another necrosis promoter miR-874 was demonstrated to play a key role in oxidant induced necrosis pathways by comprising Foxo3a and caspase-8 [55]. miR-873 inhibits RIPK1/RIPK3-mediated necrotic cell death in cardiomyocytes [56]. Although miRNAs have been demonstrated to be associated with necroptosis, the underlying mechanism remains unclear. Therefore, the influence of miRNAs in the necroptosis process need to be further clarified in future studies.

\subsection{Autophagy}

Autophagy is characterized by an evolutionarily conserved process of lysosome-dependent degradation of cytoplasm components and damaged organelles such as endoplasmic reticulum, peroxisomes, and mitochondria. Generally, autophagy is an eliminating process of intracellular pathogens. Autophagy proceeds in several successive stages including induction, nucleation, expansion, and maturation [57]. In the heart, autophagy is required for the maintenance of cardiomyocytes homeostasis, while abnormal autophagy leads to the development of cardiac disorders [58,59].

Autophagy is widely implicated in cardiac pathology and it is regulated by microRNAs [28,59-64]. For example, Wang et al. demonstrated that miR-188-3p functions as an autophagy inhibitor in myocardial infarction. The level of miR-188-3p is reduced both in cardiomyocytes treated with anxia/reoxygenation (A/R) and mice upon myocardial infarction, but enforced expression of miR-188-3p can alleviate autophagic cell death in cardiomyocytes induced by A/R. In the mouse model of myocardial infarction, overexpression of miR-188-3p attenuates autophagy and infarct 
size through targeting autophagy mediator ATG7. These findings suggest that miR-188-3p plays a cardioprotective role in myocardial infarction by inhibiting autophagy [59]. Another research work revealed that miR-145 repairs infarcted myocardium by accelerating cardiomyocyte autophagy in a rabbit model of myocardial infarction [28]. miR-19a-3p/19b-3p suppresses autophagy of human cardiac fibroblasts through targeting transforming growth factor (TGF)- $\beta$ receptor II mRNA. In the circulation of heart failure patients, the level of miR-19a-3p/19b-3p is very low. The miR-19a-3p/19b-3p overexpression promotes collagen $1 \alpha 2$ and fibronectin synthesis in human cardiac fibroblasts, which can be interrupted by autophagy inhibitor. This enlightens the influence of miR-19a-3p/19b-3p on the autophagic process [61]. Bim is another downstream target of miR-19a-regulated-autophagy pathway [62]. miRNAs-regulated-autophagy plays a critical role in pathological cardiomyocyte hypertrophy. Ucar et al. revealed that the miR-212/132 family regulates cardiac hypertrophy and autophagy in cardiomyocytes. miR-212/132 knockout mice exhibit a cardioprotective effect against pressure-overload-induced heart failure, while cardiomyocyte-specific overexpression of the miR-212/132 family leads to pathological cardiac hypertrophy. Further studies identified that transcription factor FoxO3 is a target of miR-212/132 in autophagic signal pathway [64]. Taken together, miRNAs are closely linked to autophagy-related cardiac pathology, however, whether mRNAs depdendent autophagy provokes or inhibits cardiac disorders seems to be confused, and hence this necessitates further elucidation of the underlying molecular mechanism.

In summary, the broad involvement of miRNAs in cardiac cell death has been exhibited. A growing number of miRNAs as well as their targets have been identified in apoptosis, necroptosis, and autophagy regulation. Nevertheless, more regulatory pathways and the link between different pathways of miRNA regulating cardiac cell death need to be clarified urgently.

\section{How Do MicroRNAs Regulate Myocardial Infarction?}

The significance of miRNAs in regulating myocardial infarction has been well emphasized by multiple studies. Several miRNAs are downregulated/upregulated depending on the type of myocardial injury. The significant changes in their expression pattern upon myocardial infarction highlights their contribution in regulation of pathogenesis of MI. The miR-15 family including six closely related-miRNAs are upregulated both in the mouse and pig models of myocardial infarction [65]. The level of miR-34 family members (miR-34a, $-34 b$, and -34c) are significantly increased in mice subjected to MI [66]. miR-499 is downregulated in the mouse model of MI [67]. miR-320 expression is significantly decreased in the heart following I/R injury [68]. miR-24 expression is depressed in heart tissue after myocardial infarction [69]. Additionally, the levels of expression of miR-1 [70], miR-16 [71], miR-21 [39], miR-92a [72], miR-195 [73], miR-208 [74], miR-375 [75], miR-494 [76], miR-103/107, miR-325, and miR-874 are significantly upregulated in heart tissue myocardial infarction, while the levels of tissue miR-133a/b [74], miR-214 [77], miR-873 [56], miR-2861 [54], miR-30b [52], miR-188-3p [59], and miR-145 [28] are decreased upon MI.

MicroRNAs play a critical role in myocardial infarction through regulating apoptotic, necrotic, and autophagic cell death. Among the aberrantly expressed miRNAs in MI, several typical miRNAs are chosen here to illustrate how miRNAs regulate myocardial infarction. miR-494 can protect hearts against I/R-induced injury by targeting both pro- and anti-apoptotic proteins. miR-494 transgenic mice exhibit improved recovery of contractile performance accompanied by apoptosis inhibition during the reperfusion period [76]. Down-regulation of miR-320 suppresses cardiomyocyte apoptosis and improves heart function against myocardial infarction [47]. Inhibition of miR-103/107 elevation reduces infarct size and improves cardiac function after ischemia/ reperfusion by alleviating cardiac cell programmed necrosis [27]. miR-874 displays its potential positive influence on myocardial necrosis by suppressing Foxo3a, which is implicated in the development of myocardial infarction [55]. Similarly, other microRNAs such as miR-873 and miR-2861 [54] can reduce myocardial infarct size by attenuating ischemia/reperfusion induced programmed necrotic cell death [56]. Cardiac-specific expression of miR-30b in transgenic mice exhibits reduced necrosis and myocardial infarct size in 
ischemia/reperfusion [52]. miR-188-3p suppresses autophagy and myocardial infarction by targeting ATG7 [59], While myocardial infarction is promoted by miR-325 regulated autophagic cell death [60]. miR-145 repairs infracted myocardium by accelerating cardiomyocyte autophagy [28] Collectively, these findings depict the complicated network of miRNAs in myocardial infarction.

\section{MicroRNAs Regulate Cardiomyocyte Regeneration in Myocardial Infarction}

The mammalian heart has only a limited regenerative capacity. The hearts of neonatal animals have a remarkable capability for cardiac repair and regeneration following injury caused by myocardial infarction [78]. However, the regenerative capacity largely declines within seven days after birth and remains very low in the adult heart [78]. Thus, the activation of endogenous heart regeneration and the triggering of cardiomyocytes renewal could provide new clues for the therapy to treat myocardial infarction. Different approaches have been proposed to regenerate new cardiomyocytes: (1) to promote resident cardiomyocytes proliferation by inducing them to re-enter the cell cycle; (2) to activate endogenous stem cells or progenitors such as cardiac stem cells (CSCs) differentiation; (3) to stimulate endogenous regeneration through direct reprogramming from cardiac fibroblasts into cardiomyocytes [26]. It has been demonstrated that miRNAs are critical regulators of these processes and exhibit as potential new therapeutic targets for MI.

Like many other organ development processes, mammalian heart development and homeostasis is tightly regulated by miRNAs (Figure 3). As cardiomyocytes stop proliferating shortly after birth in mice, the miRNA expression profile in this period shows a series of changes related to the progressive decrease of cardiomyocytes proliferation capacity. The miR-17 92 cluster including miR-17, miR-18a, miR-19a, miR-19b, miR-20a, and miR-92a, has been demonstrated to be associated with cardiomyocytes proliferation [79]. Overexpression of this cluster using cardiomyocyte-specific knock-in mice substantially raises the total number of cardiomyocytes, which increases the wall thickness and left ventricle dimension, while conditional knockout of this cluster in the heart notably reduces cardiomyocyte proliferation and heart weight at birth [79]. However, overexpression of miR-17 92 in the adult heart alleviates MI injury responses [79]. Recently, miR-548c-3p, miR-509-3p, and miR-23b-3p were shown to induce significant proliferation in adult cardiomyocytes through translational inhibition of Meis1 and thereby regulate cell-cycle progression [80]. In contrast, miR-590 and miR-199a encourage cell cycle re-entry of adult cardiomyocytes ex vivo and promote cardiomyocyte proliferation in neonatal mice. Interestingly, a single administration of synthetic miR-590/miR-199a-lipid formulations was sufficient to stimulate cardiac repair and restoration of cardiac function [81,82]. In mice suffering MI, miR-590 and miR-199a completely improved cardiac function through stimulation of cardiac regenerative processes [81]. In addition, the enhancement of miRNA-204 expression promotes cardiomyocyte proliferation in both neonatal and adult cardiomyocytes by targeting Jarid2. Transgenic mice with the cardiac-specific overexpression of miRNA-204 exhibited excessive cardiomyocyte proliferation throughout the embryonic and adult stages which led to a pronounced increase in ventricular mass [83].

Many other miRNAs have been demonstrated to inhibit cardiomyocytes proliferation. The miR-15 family (including miR-15a, miR-15b, miR-16, miR-195, and miR-497) is a potential inhibitor of cardiomyocytes proliferation [84]. Inhibition of miR-15b and miR-16 extends the period of cardiomyocyte proliferation after birth in mouse [84]. However, the overexpression of miR-195 in transgenic mice exhibits a marked reduction in the number of cells undergoing mitosis and increased proportion of multinucleated cardiomyocytes at the early postnatal period [85]. The heart from these mice displayed cardiac malformations including ventricular septal defect [85]. In addition, miR-133a is known as an anti-proliferation factor in cardiomyocytes. Genetic deletion of miR-133a leads to $50 \%$ embryonically lethality rate in mice, and surviving mice acquire cardiomyopathy as well as heart failure due to aberrant proliferation of cardiomyocytes [86]. In model system like zebrafish, the depletion of miR-133 induces cardiomyocytes proliferation and promotes quick recovery of the injured heart, while overexpression of miR-133 inhibits this process [87]. 


\section{Cardiac regeneration in myocardium infarction}

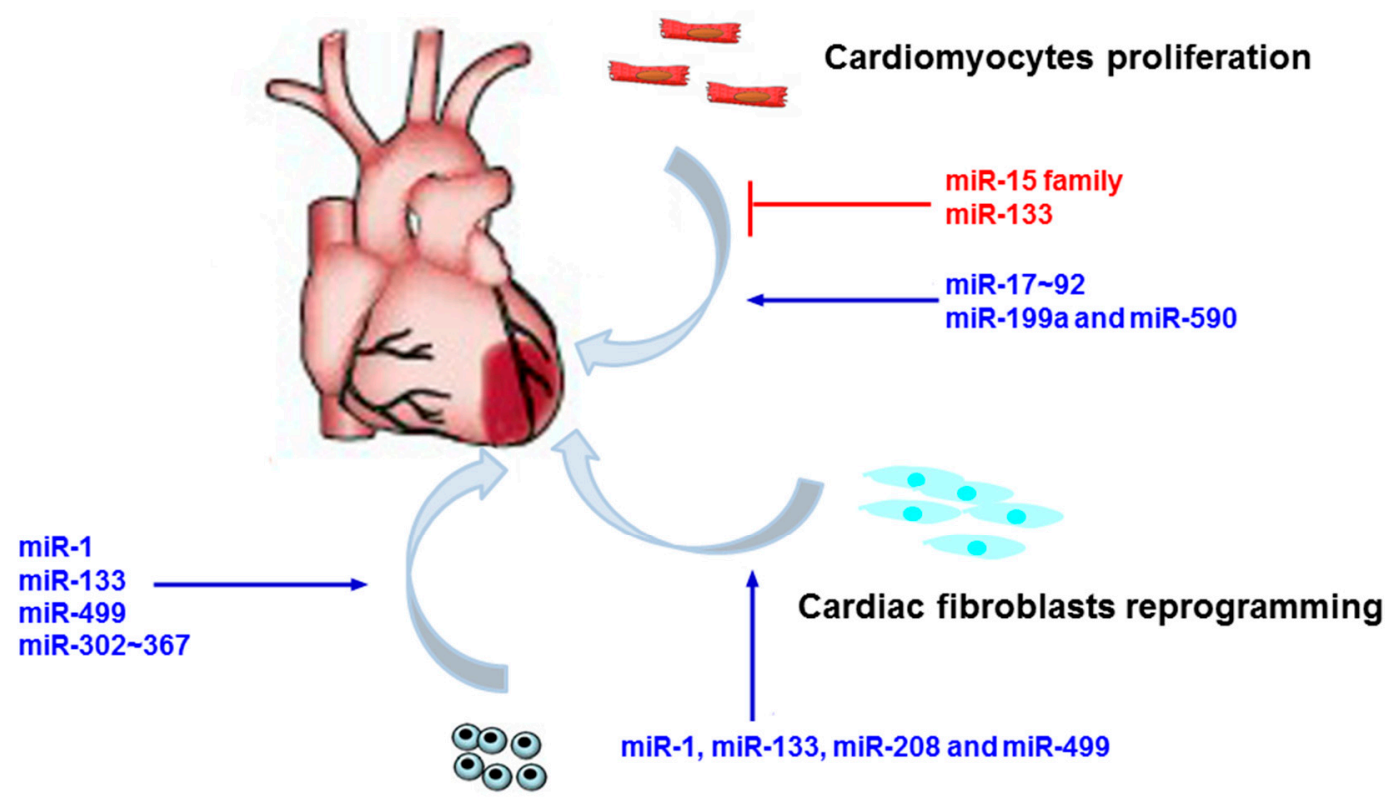

Stem/progenitor cells differentiation

Figure 3. Summary of miRNAs functioning to regulate cardiac regeneration in MI. Cardiomyocytes proliferation, cardiac fibroblasts reprogramming and stem/progenitor cells differentiation mediated by miRNAs are shown in the figure. See text for detailed explanations. Both blue and grey arrows represent the promotion effect. $\mathrm{T}$ bars represent the inhibition effect.

Stimulating proliferation and differentiation of endogenous stem cells or progenitors like cardiac progenitor cells (CPCs) is another alternative strategy to compensate cardiomyocytes loss. miRNAs are linked to such processes and their actions promote cardiomyocytes regeneration [88]. miR-1 and miR-133 family are rapidly upregulated during in vitro differentiation of adult CPCs [89]. Overexpression of miR-1 family enhances the cardiac differentiation of CPCs, whereas overexpression of miR-133 family does not modulate this process but protects CPCs against apoptosis [89]. Likewise, forced expression of miR-499 in human CPCs can promote the differentiation to CMs in vitro [90]. miR-300 is a poorly characterized microRNA in the Dlk1-Dio3 microRNA cluster, which positively regulates Bmi1 in CPCs. Forced expression of miR-300 in CPCs promoted an improved stemness signature but significantly reduced key cardiac transcription factors, including Nkx2.5 and Tbx5 [91]. In the early development of the heart, some miRNAs were shown to maintain tissue-specific progenitors [92]. miR-302 367 clusters (including miR-302a, miR-302b, miR-302c, miR-302d and miR-367) encourage embryonic cardiomyocytes proliferation by targeting CPCs [93]. miR-302 367 gain of function leads to cardiomegaly in fetal and juvenile hearts with a more undifferentiated cardiomyocytes phenotype, similar to mature hearts. The infarcted mouse hearts treated systemically with miR-302 367 exhibit decreased cardiac fibrosis and improved heart function [93]. In addition, forced expression of miR-499 in human CPCs could promote the differentiation to CMs in vitro [90].

Cardiac fibroblasts comprise over $50 \%$ of the whole cells in the heart [94]. Fibroblasts can be successfully reprogrammed into cardiomyocytes with a combination of the transcription factor, which reduces infarct size of hearts and improves cardiac function in mice upon MI [95]. Several studies demonstrate the involvement of miRNAs in mediating fibroblasts reprogramming. For instance, miR-1, miR-133, miR-208 together with miR-499 (named miR combo) are sufficient to induce efficient reprogramming of cardiac fibroblasts into cardiomyocytes both in vitro and in vivo [96]. 
This combination promoted a progressive improvement in cardiac function as well as reduced fibrosis over a 3-month period after MI [97].

\section{MicroRNAs as Biomarkers and Clinical Therapeutic Targets in Myocardial Infarction}

An ideal biomarker usually fulfills three criteria: good accessibility, predictability of detection, and robust reliability [98]. Currently more sensitive and specific biomarkers are required in clinical practice. Although serum troponin is now being used as a diagnostic marker for MI, its delayed release time often leads to low sensitivity. Recently, the identification of alterations of miRNAs as a cardiac response to ischemia has motivated investigations for new perspectives of clinical research. Circulating miRNAs in the blood have recently emerged as potential biomarkers for the diagnosis or prognosis of MI due to their stability and specificity in plasma. A large body of studies explored the fact that miRNAs are leaked from the heart into the circulation after myocardial injury $[99,100]$, during which their expression is elevated and dynamic [101,102]. Circulating miRNAs are stable and can be easily quantified by real-time PCR assay. Among these abundant miRNAs in the heart, four cardiac-enriched miRNAs (miR-208, miR-499, miR-1, and miR-133) are consistently found to be increased in the plasma of acute myocardial infarction patients [74,103,104]. For example, Wang et al. measured circulating levels of miRNAs in patients with AMI as well as in healthy subjects. They observed a significant up-regulation of miR-1, miR-133, and miR-499 in the circulation of AMI patients [102]. Interestingly, miR-208a is highly detectable in $91 \%$ of AMI patients but not in healthy controls. In addition, side-to-side comparisons of receiver operating characteristic (ROC) curves reveal that miR-208a has advantages over troponin in the early phase of MI. Other small-scale studies also confirmed that these four miRNAs are linked to MI in cultured cardiomyocytes as well as in patients $[103,105,106]$. Recently, the efficiency of circulating miR-92a and miR-181a as potential novel biomarkers for diagnosis of AMI patients was reported $[107,108]$. Based on these results, further large-scale studies on patient populations are required to confirm their utility as biomarkers. Oerlemans et al. determined the potential value of circulating miR-1, miR-21, miR-146a, miR-208a, and miR-499 in a cohort of 332 suspected acute coronary syndrome (ACS) patients, and found that the combination of miR-1, miR-21, and miR-499 could have a higher diagnostic value than hs-troponin $\mathrm{T}$ [109]. In a study with a total of 424 patients presenting with ACS, miR-208b and miR-499 showed a higher expression level in MI patients compared with non-MI patients, and they were well correlated with cardiac troponins. However, their diagnostic value is not superior to cardiac troponins. [104]. Another study performed with 1155 patients with acute chest pain also confirmed that none of the tested miRNAs outperformed cTnT [110]. These identified circulating miRNAs as diagnostic biomarkers for MI are listed in Table 1. Although the potential value of miRNAs as biomarkers has been established in small-scale studies, it is difficult to validate them in large cohorts of patients with MI. In addition, the methods of miRNAs detection need to be optimized. The standardized assays for the detection of miRNAs in patients may reduce the inconsistency and miRNAs may become potential biomarkers for diagnosis of MI patients. More prospective studies are underway to assess the diagnostic value of miRNAs as biomarkers.

On the other hand, predicting the outcome after MI can offer information about cardiac dysfunction [111]. However, there are still no appropriate prognostic biomarkers recommended for clinical practice, although a number of candidate prognostic biomarker of MI have been identified, such as neutrophil gelatinase-associated lipocalin (NGAL), brain natriuretic peptide (BNP), and soluble ST2 (sST2) [111]. Among them, BNP is currently considered to be an optimal prognostic biomarker for MI, however, it lacks public acceptance due to its long half-life and fluctuant levels in plasma upon MI [112]. The sensitivity and specificity of circulating miRNAs have an attractive prognostic value in response to MI, and relevant research is being designed and carried out.

The discovery of miRNAs involvement in the cardiac response to ischemia has captured a lot of attention in exploring the therapeutic regulation of miRNA. So far, several strategies have been undertaken to enhance the levels of miRNAs with salutary functions or to knock down the expression of pathogenic miRNAs in vivo. miRNA mimics are synthesized to up-regulate the expression of interest 
miRNA with double-stranded structure, in which one "guide" strand is identical to the mature miRNA and the other "passenger" strand is complementary to its guide strand of miRNA with position-specific chemical modifications to ensure location into the RISC [113]. On the contrary, chemical modifications such as 2'-O-methyl-modified oligonucleotides with perfect complementarity to target miRNAs (antagomiR), are the most often used techniques in anti-miRNAs strategy. Besides, $2^{\prime}$-O-methoxyethyl (MOE)-modified oligonucleotides and locked nucleic acid (LNA)-modified oligonucleotides have also been applied to inhibit miRNA activity. Numerous studies support this strategy by showing the delivery of antagomiR in animals effectively reduced target miRNA levels for a long time with low toxicity [114]. For example, Care et al. observed inhibition of miR-133 using an antagomiR blocked cardiac hypertrophy in mice [115]. Systemic delivery of LNA-modified oligonucleotides (antimiR-208a) during heart failure effectively improved cardiac function and survival in rats [116]. Although tremendous progress has been made in miRNAs-based therapeuticsfor MI, the most important challenges such as the stability in specific organs or cell types remain to be solved before their clinical application.

Table 1. Circulating miRNAs as diagnostic biomarkers for MI.

\begin{tabular}{|c|c|c|c|}
\hline miRNAs & Study Design & Source & Reference \\
\hline $\operatorname{miR}-221-3 p$ & 27 AMI a patients; 16 control subjects & Plasma & [117] \\
\hline $\begin{array}{c}\text { miR-21 } \\
\text { miR-423 }\end{array}$ & 17 AMI patients; 10 control subjects & Plasma & [118] \\
\hline $\begin{array}{l}\text { miR-19b-3p } \\
\text { miR-134-5p } \\
\text { miR-186-5p }\end{array}$ & 18 AMI patients; 20 control subjects & Plasma & [119] \\
\hline miR-1 & 93 AMI patients; 66 control subjects & Plasma & [120] \\
\hline $\begin{array}{c}\text { miR-133a/b } \\
\text { miR-499 } \\
\text { miR-122 } \\
\text { miR-375 }\end{array}$ & 33 AMI patients; 17 control subjects & Plasma & {$[121]$} \\
\hline $\begin{array}{c}\text { miR-208a } \\
\text { miR-328 }\end{array}$ & 33 AMI patients; 30 control subjects & Plasma & [102] \\
\hline $\operatorname{miR}-320 a$ & 224 AMI patients; 931 non-AMI patients & Plasma & [110] \\
\hline $\operatorname{miR}-146 a$ & 106 ACS $^{\mathrm{b}}$ patients; 226 non-ACS patients & Serum & [109] \\
\hline
\end{tabular}

\section{Conclusions and Perspectives}

A lot of attention has been paid to delineate the association between miRNAs and myocardial infarction over a long time span. Accumulating evidence reveals that miRNAs function as pro- or anti-MI factors through their influence on myocardial cell death and cardiomyocyte regeneration pathways. So far, significant progress has been made to unveil the miRNAs-regulated signaling pathways of myocardial infarction, which has improved our understanding of heart pathogenesis. In fact, the expression levels of many miRNAs are highly altered in the plasma of MI patients, which emphasizes the potential of miRNAs in the diagnostics and therapeutics of MI. Notably, the miRNA-based therapeutic approach has had a remarkable outcome in a variety of experimental models of MI in animals. These advancements appear as a light in the darkness and provide real hope in the fight against myocardial infarction.

Acknowledgments: This work was supported by China Postdoctoral Science Foundation (2016M592134), and Qingdao Postdoctoral Application Research Project (2016074) and National Natural Science Foundation of China (31430041, 81230005, and 81622005).

Conflicts of Interest: The authors declare no conflict of interest. 


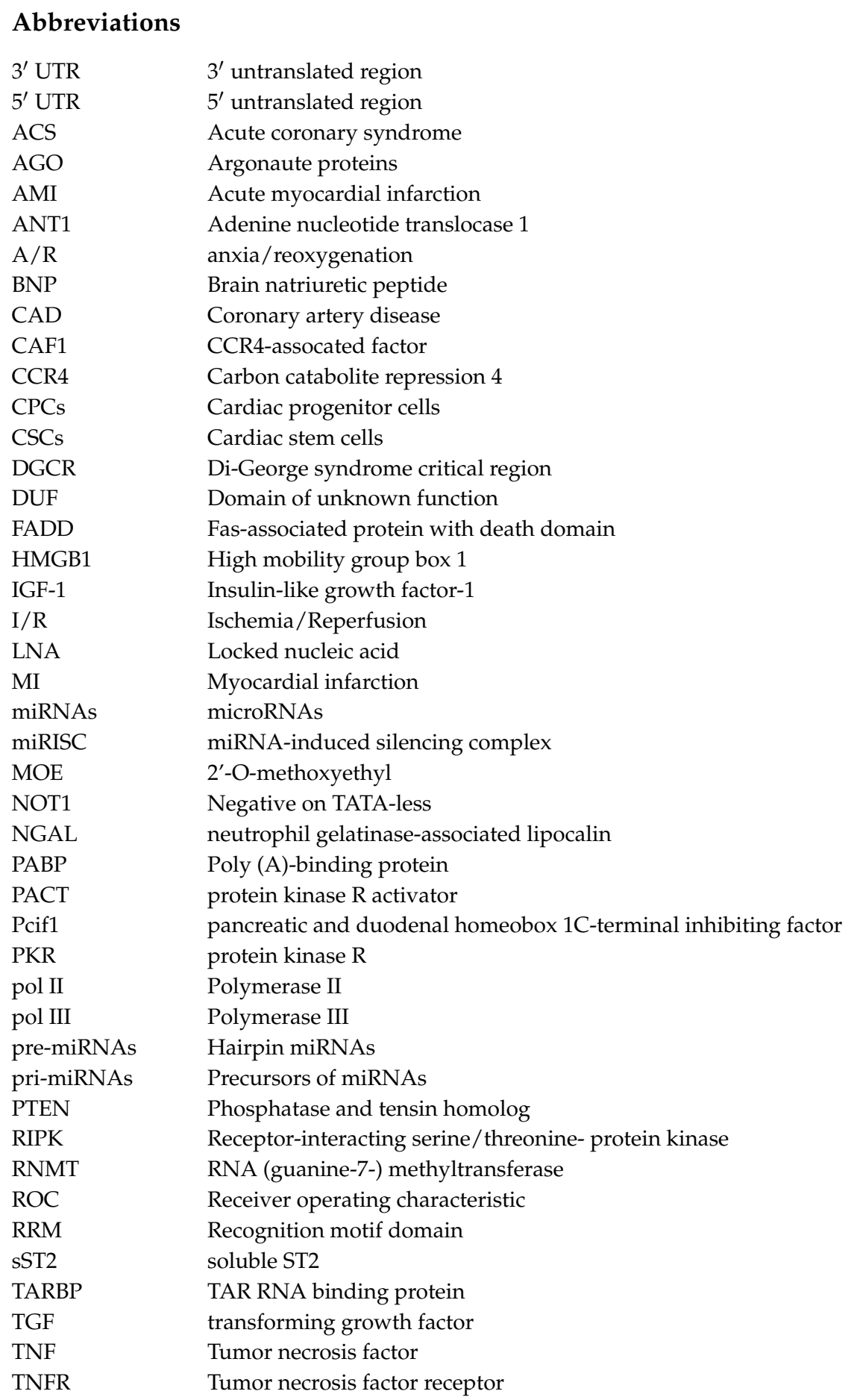

\section{References}

1. Mozaffarian, D.; Benjamin, E.J.; Go, A.S.; Arnett, D.K.; Blaha, M.J.; Cushman, M.; de Ferranti, S.; Despres, J.P.; Fullerton, H.J.; Howard, V.J.; et al. Heart disease and stroke statistics-2015 Update: A report from the american heart association. Circulation 2015, 131, 29-322. [CrossRef] [PubMed]

2. Weintraub, W.S.; Daniels, S.R.; Burke, L.E.; Franklin, B.A.; Goff, D.C., Jr.; Hayman, L.L.; Lloyd-Jones, D.; Pandey, D.K.; Sanchez, E.J.; Schram, A.P.; et al. Value of primordial and primary prevention for cardiovascular disease: A policy statement from the american heart association. Circulation 2011, 124, 967-990. [CrossRef] [PubMed]

3. Thygesen, K.; Alpert, J.S.; Jaffe, A.S.; Simoons, M.L.; Chaitman, B.R.; White, H.D. Third universal definition of myocardial infarction. J. Am. Coll. Cardiol. 2012, 60, 1581-1598. [CrossRef] [PubMed] 
4. Nichols, M.; Townsend, N.; Scarborough, P.; Rayner, M. Cardiovascular disease in Europe 2014: Epidemiological update. Eur. Heart J. 2014, 35, 2950-2959. [CrossRef] [PubMed]

5. Libby, P. Mechanisms of acute coronary syndromes and their implications for therapy. N. Engl. J. Med. 2013, 368, 2004-2013. [CrossRef] [PubMed]

6. Consortium, E.P. An integrated encyclopedia of DNA elements in the human genome. Nature 2012, 489, 57-74.

7. Wightman, B.; Ha, I.; Ruvkun, G. Posttranscriptional regulation of the heterochronic gene lin-14 by lin-4 mediates temporal pattern formation in C. Elegans. Cell 1993, 75, 855-862. [CrossRef]

8. Lee, R.C.; Feinbaum, R.L.; Ambros, V.; The, C. Elegans heterochronic gene lin-4 encodes small rnas with antisense complementarity to lin-14. Cell 1993, 75, 843-854. [CrossRef]

9. Ha, M.; Kim, V.N. Regulation of microrna biogenesis. Nat. Rev. Mol. Cell Biol. 2014, 15, 509-524. [CrossRef] [PubMed]

10. Okamura, K.; Hagen, J.W.; Duan, H.; Tyler, D.M.; Lai, E.C. The mirtron pathway generates microRNA-class regulatory RNAs in drosophila. Cell 2007, 130, 89-100. [CrossRef] [PubMed]

11. Ruby, J.G.; Jan, C.H.; Bartel, D.P. Intronic microRNA precursors that bypass drosha processing. Nature 2007, 448, 83-86. [CrossRef] [PubMed]

12. Cifuentes, D.; Xue, H.; Taylor, D.W.; Patnode, H.; Mishima, Y.; Cheloufi, S.; Ma, E.; Mane, S.; Hannon, G.J.; Lawson, N.D.; et al. A novel miRNA processing pathway independent of dicer requires argonaute 2 catalytic activity. Science 2010, 328, 1694-1698. [CrossRef] [PubMed]

13. Cheloufi, S.; Dos Santos, C.O.; Chong, M.M.; Hannon, G.J. A dicer-independent miRNA biogenesis pathway that requires ago catalysis. Nature 2010, 465, 584-589. [CrossRef] [PubMed]

14. Friedman, R.C.; Farh, K.K.; Burge, C.B.; Bartel, D.P. Most mammalian mRNAs are conserved targets of microRNAs. Genome Res. 2009, 19, 92-105. [CrossRef] [PubMed]

15. Bartel, D.P. MicroRNAs: Target recognition and regulatory functions. Cell 2009, 136, 215-233. [CrossRef] [PubMed]

16. Eulalio, A.; Tritschler, F.; Izaurralde, E. The GW182 protein family in animal cells: New insights into domains required for miRNA-mediated gene silencing. RNA 2009, 15, 1433-1442. [CrossRef] [PubMed]

17. Eulalio, A.; Helms, S.; Fritzsch, C.; Fauser, M.; Izaurralde, E. A C-terminal silencing domain in GW182 is essential for miRNA function. RNA 2009, 15, 1067-1077. [CrossRef] [PubMed]

18. Fabian, M.R.; Sonenberg, N.; Filipowicz, W. Regulation of mRNA translation and stability by microRNAs. Ann. Rev. Biochem. 2010, 79, 351-379. [CrossRef] [PubMed]

19. Nottrott, S.; Simard, M.J.; Richter, J.D. Human let-7a miRNA blocks protein production on actively translating polyribosomes. Nat. Struct. Mol. Biol. 2006, 13, 1108-1114. [CrossRef] [PubMed]

20. Petersen, C.P.; Bordeleau, M.E.; Pelletier, J.; Sharp, P.A. Short RNAs repress translation after initiation in mammalian cells. Mol. Cell 2006, 21, 533-542. [CrossRef] [PubMed]

21. Akimitsu, N.; Tanaka, J.; Pelletier, J. Translation of nonstop mRNA is repressed post-initiation in mammalian cells. EMBO J. 2007, 26, 2327-2338. [CrossRef] [PubMed]

22. Meyer, S.; Temme, C.; Wahle, E. Messenger RNA turnover in eukaryotes: Pathways and enzymes. Crit. Rev. Biochem. Mol. Biol. 2004, 39, 197-216. [CrossRef] [PubMed]

23. Yamashita, A.; Chang, T.C.; Yamashita, Y.; Zhu, W.; Zhong, Z.; Chen, C.Y.; Shyu, A.B. Concerted action of poly (A) nucleases and decapping enzyme in mammalian mRNA turnover. Nat. Struct. Mol. Biol. 2005, 12, 1054-1063. [CrossRef] [PubMed]

24. Fabian, M.R.; Mathonnet, G.; Sundermeier, T.; Mathys, H.; Zipprich, J.T.; Svitkin, Y.V.; Rivas, F.; Jinek, M.; Wohlschlegel, J.; Doudna, J.A.; et al. Mammalian miRNA RISC recruits CAF1 and PABP to affect PABP-dependent deadenylation. Mol. Cell 2009, 35, 868-880. [CrossRef] [PubMed]

25. Rehwinkel, J.; Behm-Ansmant, I.; Gatfield, D.; Izaurralde, E. A crucial role for GW182 and the DCP1:DCP2 decapping complex in miRNA-mediated gene silencing. RNA 2005, 11, 1640-1647. [CrossRef] [PubMed]

26. Boon, R.A.; Dimmeler, S. MicroRNAs in myocardial infarction. Nat. Rev. Cardiol. 2015, 12, 135-142. [CrossRef] [PubMed]

27. Wang, J.X.; Zhang, X.J.; Li, Q.; Wang, K.; Wang, Y.; Jiao, J.Q.; Feng, C.; Teng, S.; Zhou, L.Y.; Gong, Y.; et al. MicroRNA-103/107 regulate programmed necrosis and myocardial ischemia/reperfusion injury through targeting fadd. Circ. Res. 2015, 117, 352-363. [CrossRef] [PubMed] 
28. Higashi, K.; Yamada, Y.; Minatoguchi, S.; Baba, S.; Iwasa, M.; Kanamori, H.; Kawasaki, M.; Nishigaki, K.; Takemura, G.; Kumazaki, M.; et al. MicroRNA-145 repairs infarcted myocardium by accelerating cardiomyocyte autophagy. Am. J. Physiol. Heart Circ. Physiol. 2015, 309, 1813-1826. [CrossRef] [PubMed]

29. Djiadeu, P.; Kotra, L.P.; Sweezey, N.; Palaniyar, N. Surfactant protein D delays Fas- and trail-mediated extrinsic pathway of apoptosis in T cells. Apoptosis 2017. [CrossRef] [PubMed]

30. Susin, S.A.; Lorenzo, H.K.; Zamzami, N.; Marzo, I.; Snow, B.E.; Brothers, G.M.; Mangion, J.; Jacotot, E.; Costantini, P.; Loeffler, M.; et al. Molecular characterization of mitochondrial apoptosis-inducing factor. Nature 1999, 397, 441-446. [PubMed]

31. Riedl, S.J.; Shi, Y. Molecular mechanisms of caspase regulation during apoptosis. Nat. Rev. Mol. Cell Biol. 2004, 5, 897-907. [CrossRef] [PubMed]

32. Chen, L.; Willis, S.N.; Wei, A.; Smith, B.J.; Fletcher, J.I.; Hinds, M.G.; Colman, P.M.; Day, C.L.; Adams, J.M.; Huang, D.C. Differential targeting of prosurvival Bcl-2 proteins by their BH3-only ligands allows complementary apoptotic function. Mol. Cell 2005, 17, 393-403. [CrossRef] [PubMed]

33. Narula, J.; Pandey, P.; Arbustini, E.; Haider, N.; Narula, N.; Kolodgie, F.D.; Dal Bello, B.; Semigran, M.J.; Bielsa-Masdeu, A.; Dec, G.W.; et al. Apoptosis in heart failure: Release of cytochrome c from mitochondria and activation of caspase-3 in human cardiomyopathy. Proc. Natl. Acad. Sci. USA 1999, 96, 8144-8149. [CrossRef] [PubMed]

34. Guo, A.; Salomoni, P.; Luo, J.; Shih, A.; Zhong, S.; Gu, W.; Pandolfi, P.P. The function of PML in p53-dependent apoptosis. Nat. Cell Biol. 2000, 2, 730-736. [PubMed]

35. Joshi, S.; Wei, J.; Bishopric, N.H. A cardiac myocyte-restricted lin28/let-7 regulatory axis promotes hypoxia-mediated apoptosis by inducing the akt signaling suppressor PIK3IP1. Biochim. Biophys. Acta 2016, 1862, 240-251. [CrossRef] [PubMed]

36. Garofalo, M.; Jeon, Y.J.; Nuovo, G.J.; Middleton, J.; Secchiero, P.; Joshi, P.; Alder, H.; Nazaryan, N.; di Leva, G.; Romano, G.; et al. miR-34a/c-dependent PDGFR- $\alpha / \beta$ downregulation inhibits tumorigenesis and enhances TRAIL-induced apoptosis in lung cancer. PLoS ONE 2013, 8, e67581. [CrossRef] [PubMed]

37. Hermeking, H. The miR-34 family in cancer and apoptosis. Cell Death Differ. 2010, 17, 193-199. [CrossRef] [PubMed]

38. Cheng, Y.; Zhu, P.; Yang, J.; Liu, X.; Dong, S.; Wang, X.; Chun, B.; Zhuang, J.; Zhang, C. Ischaemic preconditioning-regulated miR-21 protects heart against ischaemia/reperfusion injury via anti-apoptosis through its target PDCD4. Cardiovasc. Res. 2010, 87, 431-439. [CrossRef] [PubMed]

39. Huang, W.; Tian, S.S.; Hang, P.Z.; Sun, C.; Guo, J.; Du, Z.M. Combination of microRNA-21 and microRNA-146a attenuates cardiac dysfunction and apoptosis during acute myocardial infarction in mice. Mol. Ther. Nucleic Acids 2016, 5, e296. [CrossRef] [PubMed]

40. Wei, C.; Li, L.; Gupta, S. NF-kB-mediated miR-30b regulation in cardiomyocytes cell death by targeting Bcl-2. Mol. Cell. Biochem. 2014, 387, 135-141. [CrossRef] [PubMed]

41. Wang, X.; Ha, T.; Zou, J.; Ren, D.; Liu, L.; Zhang, X.; Kalbfleisch, J.; Gao, X.; Williams, D.; Li, C. MicroRNA-125b protects against myocardial ischaemia/reperfusion injury via targeting p53-mediated apoptotic signalling and TRAF6. Cardiovasc. Res. 2014, 102, 385-395. [CrossRef] [PubMed]

42. He, S.; Liu, P.; Jian, Z.; Li, J.; Zhu, Y.; Feng, Z.; Xiao, Y. miR-138 protects cardiomyocytes from hypoxia-induced apoptosis via MLK3/JNK/c-jun pathway. Biochem. Biophys. Res. Commun. 2013, 441, 763-769. [CrossRef] [PubMed]

43. Ke, Z.P.; Xu, P.; Shi, Y.; Gao, A.M. MicroRNA-93 inhibits ischemia-reperfusion induced cardiomyocyte apoptosis by targeting PTEN. Oncotarget 2016, 7, 28796-28805. [CrossRef] [PubMed]

44. Li, R.; Geng, H.H.; Xiao, J.; Qin, X.T.; Wang, F.; Xing, J.H.; Xia, Y.F.; Mao, Y.; Liang, J.W.; Ji, X.P. $\mathrm{miR}-7 \mathrm{a} / \mathrm{b}$ attenuates post-myocardial infarction remodeling and protects $\mathrm{H} 9 \mathrm{c} 2$ cardiomyoblast against hypoxia-induced apoptosis involving Sp1 and PARP-1. Sci. Rep. 2016, 6, 29082. [CrossRef] [PubMed]

45. Wang, Y.; Ouyang, M.; Wang, Q.; Jian, Z. MicroRNA-142-3p inhibits hypoxia/reoxygenationinduced apoptosis and fibrosis of cardiomyocytes by targeting high mobility group box 1. Int. J. Mol. Med. 2016, 38, 1377-1386. [PubMed]

46. Wu, Z.; Qi, Y.; Guo, Z.; Li, P.; Zhou, D. miR-613 suppresses ischemia-reperfusion-induced cardiomyocyte apoptosis by targeting the programmed cell death 10 gene. Biosci. Trends 2016, 10, 251-257. [CrossRef] [PubMed] 
47. Song, C.L.; Liu, B.; Diao, H.Y.; Shi, Y.F.; Zhang, J.C.; Li, Y.X.; Liu, N.; Yu, Y.P.; Wang, G.; Wang, J.P.; et al. Down-regulation of microRNA-320 suppresses cardiomyocyte apoptosis and protects against myocardial ischemia and reperfusion injury by targeting IGF-1. Oncotarget 2016, 7, 39740-39757. [CrossRef] [PubMed]

48. Liang, W.; Guo, J.; Li, J.; Bai, C.; Dong, Y. Downregulation of miR-122 attenuates hypoxia/reoxygenation (H/R)-induced myocardial cell apoptosis by upregulating GATA-4. Biochem. Biophys. Res. Commun. 2016, 478, 1416-1422. [CrossRef] [PubMed]

49. Zou, Y.; Liu, W.; Zhang, J.; Xiang, D. miR-153 regulates apoptosis and autophagy of cardiomyocytes by targeting MCL-1. Mol. Med. Rep. 2016, 14, 1033-1039. [CrossRef] [PubMed]

50. Wang, J.X.; Gao, J.; Ding, S.L.; Wang, K.; Jiao, J.Q.; Wang, Y.; Sun, T.; Zhou, L.Y.; Long, B.; Zhang, X.J.; et al. Oxidative modification of miR-184 enables it to target Bcl-xL and Bcl-w. Mol. Cell 2015, 59, 50-61. [CrossRef] [PubMed]

51. Adameova, A.; Goncalvesova, E.; Szobi, A.; Dhalla, N.S. Necroptotic cell death in failing heart: Relevance and proposed mechanisms. Heart Fail. Rev. 2016, 21, 213-221. [CrossRef] [PubMed]

52. Wang, K.; An, T.; Zhou, L.Y.; Liu, C.Y.; Zhang, X.J.; Feng, C.; Li, P.F. E2F1-regulated miR-30b suppresses cyclophilin D and protects heart from ischemia/reperfusion injury and necrotic cell death. Cell Death Differ. 2015, 22, 743-754. [CrossRef] [PubMed]

53. Liu, J.; van Mil, A.; Vrijsen, K.; Zhao, J.; Gao, L.; Metz, C.H.; Goumans, M.J.; Doevendans, P.A.; Sluijter, J.P. MicroRNA-155 prevents necrotic cell death in human cardiomyocyte progenitor cells via targeting RIP1. J. Cell. Mol. Med. 2011, 15, 1474-1482. [CrossRef] [PubMed]

54. Wang, K.; Long, B.; Li, N.; Li, L.; Liu, C.Y.; Dong, Y.H.; Gao, J.N.; Zhou, L.Y.; Wang, C.Q.; Li, P.F. MicroRNA-2861 regulates programmed necrosis in cardiomyocyte by impairing adenine nucleotide translocase 1 expression. Free Radic. Biol. Med. 2016, 91, 58-67. [CrossRef] [PubMed]

55. Wang, K.; Liu, F.; Zhou, L.Y.; Ding, S.L.; Long, B.; Liu, C.Y.; Sun, T.; Fan, Y.Y.; Sun, L.; Li, P.F. miR-874 regulates myocardial necrosis by targeting caspase-8. Cell Death Dis. 2013, 4, e709. [CrossRef] [PubMed]

56. Wang, K.; Liu, F.; Liu, C.Y.; An, T.; Zhang, J.; Zhou, L.Y.; Wang, M.; Dong, Y.H.; Li, N.; Gao, J.N.; et al. The long noncoding RNA NRF regulates programmed necrosis and myocardial injury during ischemia and reperfusion by targeting miR-873. Cell Death Differ. 2016, 23, 1394-1405. [CrossRef] [PubMed]

57. Zhou, L.; Ma, B.; Han, X. The role of autophagy in angiotensin II-induced pathological cardiac hypertrophy. J. Mol. Endocrinol. 2016, 57, 143-152. [CrossRef] [PubMed]

58. Gong, G.; Song, M.; Csordas, G.; Kelly, D.P.; Matkovich, S.J.; Dorn, G.W. Parkin-mediated mitophagy directs perinatal cardiac metabolic maturation in mice. Science 2015, 350, 2459. [CrossRef] [PubMed]

59. Wang, K.; Liu, C.Y.; Zhou, L.Y.; Wang, J.X.; Wang, M.; Zhao, B.; Zhao, W.K.; Xu, S.J.; Fan, L.H.; Zhang, X.J.; et al. APF lncRNA regulates autophagy and myocardial infarction by targeting miR-188-3p. Nat. Commun. 2015, 6, 6779. [CrossRef] [PubMed]

60. Bo, L.; Su-Ling, D.; Fang, L.; Lu-Yu, Z.; Tao, A.; Stefan, D.; Kun, W.; Pei-Feng, L. Autophagic program is regulated by miR-325. Cell Death Differ. 2014, 21, 967-977. [CrossRef] [PubMed]

61. Zou, M.; Wang, F.; Gao, R.; Wu, J.; Ou, Y.; Chen, X.; Wang, T.; Zhou, X.; Zhu, W.; Li, P.; et al. Autophagy inhibition of hsa-miR-19a-3p/19b-3p by targeting TGF- $\beta$ R II during TGF- $\beta 1$-induced fibrogenesis in human cardiac fibroblasts. Sci. Rep. 2016, 6, 24747. [CrossRef] [PubMed]

62. Gao, Y.H.; Qian, J.Y.; Chen, Z.W.; Fu, M.Q.; Xu, J.F.; Xia, Y.; Ding, X.F.; Yang, X.D.; Cao, Y.Y.; Zou, Y.Z.; et al. Suppression of bim by microRNA-19a may protect cardiomyocytes against hypoxia-induced cell death via autophagy activation. Toxicol. Lett. 2016, 257, 72-83. [CrossRef] [PubMed]

63. Su, M.; Wang, J.; Wang, C.; Wang, X.; Dong, W.; Qiu, W.; Wang, Y.; Zhao, X.; Zou, Y.; Song, L.; et al. MicroRNA-221 inhibits autophagy and promotes heart failure by modulating the p27/CDK2/mTOR axis. Cell Death Differ. 2015, 22, 986-999. [CrossRef] [PubMed]

64. Ucar, A.; Gupta, S.K.; Fiedler, J.; Erikci, E.; Kardasinski, M.; Batkai, S.; Dangwal, S.; Kumarswamy, R.; Bang, C.; Holzmann, A.; et al. The miRNA-212/132 family regulates both cardiac hypertrophy and cardiomyocyte autophagy. Nat. Commun. 2012, 3, 1078. [CrossRef] [PubMed]

65. Hullinger, T.G.; Montgomery, R.L.; Seto, A.G.; Dickinson, B.A.; Semus, H.M.; Lynch, J.M.; Dalby, C.M.; Robinson, K.; Stack, C.; Latimer, P.A.; et al. Inhibition of miR-15 protects against cardiac ischemic injury. Circ. Res. 2012, 110, 71-81. [CrossRef] [PubMed] 
66. Bernardo, B.C.; Gao, X.M.; Winbanks, C.E.; Boey, E.J.; Tham, Y.K.; Kiriazis, H.; Gregorevic, P.; Obad, S.; Kauppinen, S.; Du, X.J.; et al. Therapeutic inhibition of the miR-34 family attenuates pathological cardiac remodeling and improves heart function. Proc. Natl. Acad. Sci. USA 2012, 109, 17615-17620. [CrossRef] [PubMed]

67. Wang, J.X.; Jiao, J.Q.; Li, Q.; Long, B.; Wang, K.; Liu, J.P.; Li, Y.R.; Li, P.F. miR-499 regulates mitochondrial dynamics by targeting calcineurin and dynamin-related protein-1. Nat. Med. 2011, 17, 71-78. [CrossRef] [PubMed]

68. Ren, X.P.; Wu, J.; Wang, X.; Sartor, M.A.; Qian, J.; Jones, K.; Nicolaou, P.; Pritchard, T.J.; Fan, G.C. MicroRNA-320 is involved in the regulation of cardiac ischemia/reperfusion injury by targeting heat-shock protein 20. Circulation 2009, 119, 2357-2366. [CrossRef] [PubMed]

69. Chen, Z.; Lu, S.; Xu, M.; Liu, P.; Ren, R.; Ma, W. Role of miR-24, furin, and transforming growth factor- $\beta 1$ signal pathway in fibrosis after cardiac infarction. Med. Sci. Monit. 2017, 23, 65-70. [CrossRef] [PubMed]

70. Pan, Z.; Sun, X.; Ren, J.; Li, X.; Gao, X.; Lu, C.; Zhang, Y.; Sun, H.; Wang, Y.; Wang, H.; et al. miR-1 exacerbates cardiac ischemia-reperfusion injury in mouse models. PLoS ONE 2012, 7, e50515. [CrossRef] [PubMed]

71. Li, X.; Hu, H.; Wang, Y.; Xue, M.; Cheng, W.; Xuan, Y.; Yin, J.; Yang, N.; Yan, S. Valsartan ameliorates KIR2.1 in rats with myocardial infarction via the NF-kB-miR-16 pathway. Gene 2016, 590, 201-209. [CrossRef] [PubMed]

72. Liu, H.; Li, G.; Zhao, W.; Hu, Y. Inhibition of miR-92a may protect endothelial cells after acute myocardial infarction in rats: Role of KLF2/4. Med. Sci. Monit. 2016, 22, 2451-2462. [CrossRef] [PubMed]

73. Hang, P.; Sun, C.; Guo, J.; Zhao, J.; Du, Z. BDNF-mediates down-regulation of microRNA-195 inhibits ischemic cardiac apoptosis in rats. Int. J. Biol. Sci. 2016, 12, 979-989. [CrossRef] [PubMed]

74. Bostjancic, E.; Zidar, N.; Stajer, D.; Glavac, D. MicroRNAs miR-1, miR-133a, miR-133b and miR-208 are dysregulated in human myocardial infarction. Cardiology 2010, 115, 163-169. [CrossRef] [PubMed]

75. Garikipati, V.N.; Krishnamurthy, P.; Verma, S.K.; Khan, M.; Abramova, T.; Mackie, A.R.; Qin, G.; Benedict, C.; Nickoloff, E.; Johnson, J.; et al. Negative regulation of miR-375 by interleukin-10 enhances bone marrow-derived progenitor cell-mediated myocardial repair and function after myocardial infarction. Stem Cells 2015, 33, 3519-3529. [CrossRef] [PubMed]

76. Wang, X.; Zhang, X.; Ren, X.P.; Chen, J.; Liu, H.; Yang, J.; Medvedovic, M.; Hu, Z.; Fan, G.C. MicroRNA-494 targeting both proapoptotic and antiapoptotic proteins protects against ischemia/reperfusion-induced cardiac injury. Circulation 2010, 122, 1308-1318. [CrossRef] [PubMed]

77. Yang, X.; Qin, Y.; Shao, S.; Yu, Y.; Zhang, C.; Dong, H.; Lv, G.; Dong, S. MicroRNA-214 inhibits left ventricular remodeling in an acute myocardial infarction rat model by suppressing cellular apoptosis via the phosphatase and tensin homolog (PTEN). Int. Heart J. 2016, 57, 247-250. [CrossRef] [PubMed]

78. Porrello, E.R.; Mahmoud, A.I.; Simpson, E.; Hill, J.A.; Richardson, J.A.; Olson, E.N.; Sadek, H.A. Transient regenerative potential of the neonatal mouse heart. Science 2011, 331, 1078-1080. [CrossRef] [PubMed]

79. Chen, J.; Huang, Z.P.; Seok, H.Y.; Ding, J.; Kataoka, M.; Zhang, Z.; Hu, X.; Wang, G.; Lin, Z.; Wang, S.; et al. miR-17-92 cluster is required for and sufficient to induce cardiomyocyte proliferation in postnatal and adult hearts. Circ. Res. 2013, 112, 1557-1566. [CrossRef] [PubMed]

80. Pandey, R.; Yang, Y.; Jackson, L.; Ahmed, R.P. MicroRNAs regulating meis1 expression and inducing cardiomyocyte proliferation. Cardiovasc. Regen. Med. 2016, 3, e1468. [PubMed]

81. Eulalio, A.; Mano, M.; Dal Ferro, M.; Zentilin, L.; Sinagra, G.; Zacchigna, S.; Giacca, M. Functional screening identifies miRNAs inducing cardiac regeneration. Nature 2012, 492, 376-381. [CrossRef] [PubMed]

82. Lesizza, P.; Prosdocimo, G.; Martinelli, V.; Sinagra, G.; Zacchigna, S.; Giacca, M. Single-dose intracardiac injection of pro-regenerative microRNAs improves cardiac function after myocardial infarction. Circul. Res. 2017. [CrossRef] [PubMed]

83. Liang, D.; Li, J.; Wu, Y.; Zhen, L.; Li, C.; Qi, M.; Wang, L.; Deng, F.; Huang, J.; Lv, F.; et al. MiRNA-204 drives cardiomyocyte proliferation via targeting JARID2. Int. J. Cardiol. 2015, 201, 38-48. [CrossRef] [PubMed]

84. Porrello, E.R.; Johnson, B.A.; Aurora, A.B.; Simpson, E.; Nam, Y.J.; Matkovich, S.J.; Dorn, G.W., II; van Rooij, E.; Olson, E.N. miR-15 family regulates postnatal mitotic arrest of cardiomyocytes. Circ. Res. 2011, 109, 670-679. [CrossRef] [PubMed]

85. Porrello, E.R.; Mahmoud, A.I.; Simpson, E.; Johnson, B.A.; Grinsfelder, D.; Canseco, D.; Mammen, P.P.; Rothermel, B.A.; Olson, E.N.; Sadek, H.A. Regulation of neonatal and adult mammalian heart regeneration by the miR-15 family. Proc. Natl. Acad. Sci. USA 2013, 110, 187-192. [CrossRef] [PubMed] 
86. Liu, N.; Bezprozvannaya, S.; Williams, A.H.; Qi, X.; Richardson, J.A.; Bassel-Duby, R.; Olson, E.N. MicroRNA-133a regulates cardiomyocyte proliferation and suppresses smooth muscle gene expression in the heart. Genes Dev. 2008, 22, 3242-3254. [CrossRef] [PubMed]

87. Yin, V.P.; Lepilina, A.; Smith, A.; Poss, K.D. Regulation of zebrafish heart regeneration by miR-133. Dev. Biol. 2012, 365, 319-327. [CrossRef] [PubMed]

88. Katz, M.G.; Fargnoli, A.S.; Kendle, A.P.; Hajjar, R.J.; Bridges, C.R. The role of microRNAs in cardiac development and regenerative capacity. Am. J. Physiol. Heart Circul. Physiol. 2016, 310, 528-541. [CrossRef] [PubMed]

89. Izarra, A.; Moscoso, I.; Levent, E.; Canon, S.; Cerrada, I.; Diez-Juan, A.; Blanca, V.; Nunez-Gil, I.J.; Valiente, I.; Ruiz-Sauri, A.; et al. miR-133a enhances the protective capacity of cardiac progenitors cells after myocardial infarction. Stem Cell Rep. 2014, 3, 1029-1042. [CrossRef] [PubMed]

90. Sluijter, J.P.; van Mil, A.; van Vliet, P.; Metz, C.H.; Liu, J.; Doevendans, P.A.; Goumans, M.J. MicroRNA-1 and -499 regulate differentiation and proliferation in human-derived cardiomyocyte progenitor cells. Arterioscler. Thromb. Vasc. Biol. 2010, 30, 859-868. [CrossRef] [PubMed]

91. Cruz, F.M.; Tome, M.; Bernal, J.A.; Bernad, A. miR-300 mediates Bmi1 function and regulates differentiation in primitive cardiac progenitors. Cell Death Dis. 2015, 6, e1953. [CrossRef] [PubMed]

92. Tao, G.; Wang, J.; Martin, J.F. Small RNA: From development to regeneration. Sci. Transl. Med. $2015,7,212$. [CrossRef] [PubMed]

93. Tian, Y.; Liu, Y.; Wang, T.; Zhou, N.; Kong, J.; Chen, L.; Snitow, M.; Morley, M.; Li, D.; Petrenko, N.; et al. A microRNA-hippo pathway that promotes cardiomyocyte proliferation and cardiac regeneration in mice. Sci. Transl. Med. 2015, 7, 238. [CrossRef] [PubMed]

94. Camelliti, P.; Borg, T.K.; Kohl, P. Structural and functional characterisation of cardiac fibroblasts. Cardiovasc. Res. 2005, 65, 40-51. [CrossRef] [PubMed]

95. Ieda, M.; Fu, J.D.; Delgado-Olguin, P.; Vedantham, V.; Hayashi, Y.; Bruneau, B.G.; Srivastava, D. Direct reprogramming of fibroblasts into functional cardiomyocytes by defined factors. Cell 2010, 142, 375-386. [CrossRef] [PubMed]

96. Jayawardena, T.M.; Egemnazarov, B.; Finch, E.A.; Zhang, L.; Payne, J.A.; Pandya, K.; Zhang, Z.; Rosenberg, P.; Mirotsou, M.; Dzau, V.J. MicroRNA-mediated in vitro and in vivo direct reprogramming of cardiac fibroblasts to cardiomyocytes. Circ. Res. 2012, 110, 1465-1473. [CrossRef] [PubMed]

97. Jayawardena, T.M.; Finch, E.A.; Zhang, L.; Zhang, H.; Hodgkinson, C.P.; Pratt, R.E.; Rosenberg, P.B.; Mirotsou, M.; Dzau, V.J. MicroRNA induced cardiac reprogramming in vivo: Evidence for mature cardiac myocytes and improved cardiac function. Circ. Res. 2015, 116, 418-424. [CrossRef] [PubMed]

98. Moe, K.T.; Wong, P. Current trends in diagnostic biomarkers of acute coronary syndrome. Ann. Acad. Med. Singap. 2010, 39, 210-215. [PubMed]

99. De Rosa, S.; Fichtlscherer, S.; Lehmann, R.; Assmus, B.; Dimmeler, S.; Zeiher, A.M. Transcoronary concentration gradients of circulating microRNAs. Circulation 2011, 124, 1936-1944. [CrossRef] [PubMed]

100. Akat, K.M.; Moore-McGriff, D.; Morozov, P.; Brown, M.; Gogakos, T.; Correa Da Rosa, J.; Mihailovic, A.; Sauer, M.; Ji, R.; Ramarathnam, A.; et al. Comparative RNA-sequencing analysis of myocardial and circulating small RNAs in human heart failure and their utility as biomarkers. Proc. Natl. Acad. Sci. USA 2014, 111, 11151-11156. [CrossRef] [PubMed]

101. Shi, B.; Guo, Y.; Wang, J.; Gao, W. Altered expression of microRNAs in the myocardium of rats with acute myocardial infarction. BMC Cardiovasc. Disord. 2010, 10, 11. [CrossRef] [PubMed]

102. Wang, G.K.; Zhu, J.Q.; Zhang, J.T.; Li, Q.; Li, Y.; He, J.; Qin, Y.W.; Jing, Q. Circulating microRNA: A novel potential biomarker for early diagnosis of acute myocardial infarction in humans. Eur. Heart J. 2010, 31, 659-666. [CrossRef] [PubMed]

103. Adachi, T.; Nakanishi, M.; Otsuka, Y.; Nishimura, K.; Hirokawa, G.; Goto, Y.; Nonogi, H.; Iwai, N. Plasma microRNA 499 as a biomarker of acute myocardial infarction. Clin. Chem. 2010, 56, 1183-1185. [CrossRef] [PubMed]

104. Gidlof, O.; Smith, J.G.; Miyazu, K.; Gilje, P.; Spencer, A.; Blomquist, S.; Erlinge, D. Circulating cardio-enriched microRNAs are associated with long-term prognosis following myocardial infarction. BMC Cardiovasc. Disord. 2013, 13, 12. [CrossRef] [PubMed] 
105. Kuwabara, Y.; Ono, K.; Horie, T.; Nishi, H.; Nagao, K.; Kinoshita, M.; Watanabe, S.; Baba, O.; Kojima, Y.; Shizuta, S.; et al. Increased microRNA-1 and microRNA-133a levels in serum of patients with cardiovascular disease indicate myocardial damage. Circ. Cardiovasc. Genet. 2011, 4, 446-454. [CrossRef] [PubMed]

106. Corsten, M.F.; Dennert, R.; Jochems, S.; Kuznetsova, T.; Devaux, Y.; Hofstra, L.; Wagner, D.R.; Staessen, J.A.; Heymans, S.; Schroen, B. Circulating microRNA-208b and microRNA-499 reflect myocardial damage in cardiovascular disease. Circ. Cardiovasc. Genet. 2010, 3, 499-506. [CrossRef] [PubMed]

107. Zhu, J.; Yao, K.; Wang, Q.; Guo, J.; Shi, H.; Ma, L.; Liu, H.; Gao, W.; Zou, Y.; Ge, J. Circulating miR-181a as a potential novel biomarker for diagnosis of acute myocardial infarction. Cell. Physiol. Biochem. 2016, 40, 1591-1602. [CrossRef] [PubMed]

108. Zhang, Y.; Cheng, J.; Chen, F.; Wu, C.; Zhang, J.; Ren, X.; Pan, Y.; Nie, B.; Li, Q.; Li, Y. Circulating endothelial microparticles and miR-92a in acute myocardial infarction. Biosci. Rep. 2017. [CrossRef] [PubMed]

109. Oerlemans, M.I.; Mosterd, A.; Dekker, M.S.; de Vrey, E.A.; van Mil, A.; Pasterkamp, G.; Doevendans, P.A.; Hoes, A.W.; Sluijter, J.P. Early assessment of acute coronary syndromes in the emergency department: The potential diagnostic value of circulating microRNAs. EMBO Mol. Med. 2012, 4, 1176-1185. [CrossRef] [PubMed]

110. Devaux, Y.; Mueller, M.; Haaf, P.; Goretti, E.; Twerenbold, R.; Zangrando, J.; Vausort, M.; Reichlin, T.; Wildi, K.; Moehring, B.; et al. Diagnostic and prognostic value of circulating microRNAs in patients with acute chest pain. J. Intern. Med. 2015, 277, 260-271. [CrossRef] [PubMed]

111. Goretti, E.; Wagner, D.R.; Devaux, Y. MiRNAs as biomarkers of myocardial infarction: A step forward towards personalized medicine? Trends Mol. Med. 2014, 20, 716-725. [CrossRef] [PubMed]

112. Talwar, S.; Squire, I.B.; Downie, P.F.; McCullough, A.M.; Campton, M.C.; Davies, J.E.; Barnett, D.B.; Ng, L.L. Profile of plasma N-terminal proBNP following acute myocardial infarction; correlation with left ventricular systolic dysfunction. Eur. Heart J. 2000, 21, 1514-1521. [CrossRef] [PubMed]

113. Jackson, A.L.; Burchard, J.; Leake, D.; Reynolds, A.; Schelter, J.; Guo, J.; Johnson, J.M.; Lim, L.; Karpilow, J.; Nichols, K.; et al. Position-specific chemical modification of siRNAs reduces "off-target" transcript silencing. RNA 2006, 12, 1197-1205. [CrossRef] [PubMed]

114. Krutzfeldt, J.; Kuwajima, S.; Braich, R.; Rajeev, K.G.; Pena, J.; Tuschl, T.; Manoharan, M.; Stoffel, M. Specificity, duplex degradation and subcellular localization of antagomirs. Nucleic Acids Res. 2007, 35, 2885-2892. [CrossRef] [PubMed]

115. Care, A.; Catalucci, D.; Felicetti, F.; Bonci, D.; Addario, A.; Gallo, P.; Bang, M.L.; Segnalini, P.; Gu, Y.; Dalton, N.D.; et al. MicroRNA-133 controls cardiac hypertrophy. Nat. Med. 2007, 13, 613-618. [CrossRef] [PubMed]

116. Montgomery, R.L.; Hullinger, T.G.; Semus, H.M.; Dickinson, B.A.; Seto, A.G.; Lynch, J.M.; Stack, C.; Latimer, P.A.; Olson, E.N.; van Rooij, E. Therapeutic inhibition of miR-208a improves cardiac function and survival during heart failure. Circulation 2011, 124, 1537-1547. [CrossRef] [PubMed]

117. Coskunpinar, E.; Cakmak, H.A.; Kalkan, A.K.; Tiryakioglu, N.O.; Erturk, M.; Ongen, Z. Circulating miR-221-3p as a novel marker for early prediction of acute myocardial infarction. Gene 2016, 591, 90-96. [CrossRef] [PubMed]

118. Zhang, Y.; Liu, Y.J.; Liu, T.; Zhang, H.; Yang, S.J. Plasma microRNA-21 is a potential diagnostic biomarker of acute myocardial infarction. Eur. Rev. Med. Pharmacol. Sci. 2016, 20, 323-329. [PubMed]

119. Wang, K.J.; Zhao, X.; Liu, Y.Z.; Zeng, Q.T.; Mao, X.B.; Li, S.N.; Zhang, M.; Jiang, C.; Zhou, Y.; Qian, C.; et al. Circulating miR-19b-3p, miR-134-5p and miR-186-5p are promising novel biomarkers for early diagnosis of acute myocardial infarction. Cell. Physiol. Biochem. 2016, 38, 1015-1029. [CrossRef] [PubMed]

120. Ai, J.; Zhang, R.; Li, Y.; Pu, J.; Lu, Y.; Jiao, J.; Li, K.; Yu, B.; Li, Z.; Wang, R.; et al. Circulating microRNA-1 as a potential novel biomarker for acute myocardial infarction. Biochem. Biophys. Res. Commun. 2010, 391, 73-77. [CrossRef] [PubMed]

121. D'Alessandra, Y.; Devanna, P.; Limana, F.; Straino, S.; di Carlo, A.; Brambilla, P.G.; Rubino, M.; Carena, M.C.; Spazzafumo, L.; de Simone, M.; et al. Circulating microRNAs are new and sensitive biomarkers of myocardial infarction. Eur. Heart J. 2010, 31, 2765-2773. [CrossRef] [PubMed]

(C) 2017 by the authors. Licensee MDPI, Basel, Switzerland. This article is an open access article distributed under the terms and conditions of the Creative Commons Attribution (CC BY) license (http:/ / creativecommons.org/licenses/by/4.0/). 